\title{
PASSIONATE DESCARTES: \\ A REINTERPRETATION OF THE BODY'S ROLE IN CARTESIAN THOUGHT
}

\author{
VICENTE RAGA-ROSALENY \\ https:/ / orcid.org/0000-0002-3523-1453 \\ Universidad Nacional de Colombia \\ Department of Philosophy \\ Bogotá - D. C. \\ Colombia \\ vraga@unal.edu.co
}

\section{Article info \\ CDD: 194 \\ Keywords \\ Body \\ Dualism \\ Mind \\ Passion \\ Physiology}

Received: 19.05.2020; Revised: 17.06.2020; Accepted: 18.06.2020

https://doi.org/10.1590/0100-6045.2020.V43N2.VR

Abstract: The usual reading of Descartes' "anthropological" perspective classifies it as a radical dualism with a distinction between two substances, mind and body, which experience major interaction difficulties. Through a contextualization of Descartes' physiological and psychological thought as well as through a less fragmented reading of his work, we intend to review this traditional interpretation, thereby showing its distorted character. When we pay attention to passion, a new Descartes' image as a sort of phenomenal monism appears, which is markedly different from the legendary image typically associated with him, even today. 


\section{INTRODUCTION}

The customary image of the French thinker René Descartes disseminated in some systematic philosophy is that of a rationalist with unconvincing theological commitments involved with unequal success in modern mathematics and physics. Currently, this image of the socalled father of modern philosophy also has a clear negative connotation, Descartes' legend presents him as the main defender of a pernicious "official doctrine" 1 characterized by infallible introspection, epistemic and ontic mental privacy (first person authority), transparency of mind, and especially a radical dualism as the basis of all these problematic features. ${ }^{2}$

We might offer a hopeful perspective to this description or perhaps negative diagnosis: the conceptual analysis of twentieth-century philosophy of language and mind, as well as the experimental advances in cognitive sciences and neuropsychology, would have rebutted the Cartesian myth.

\footnotetext{
${ }^{1}$ See Ryle, The Concept of Mind, 1-5.

2 See, for example, Boghossian, "Content and self-knowledge", 151; Churchland, Matter and Consciouness, 18-21; Fodor, "Methodological solipsism", 228; McDowell, Mind and World, 101ff; Moran, Authority and Estrangement, 5; Putnam, The Threefold Cord, 128; Searle, Minds, Brains and Science, 10ff; Shoemaker, The First Person Perspective, 25ff, Strawson, Freedom and Resentment, 169. In calling this the Cartesian legend what I mean is that it does not describe the position of Descartes himself, for whom it is named, and the true Descartes's connections with science in his time and place. Of course, things are different in the field of the history of philosophy, where there has been an important work of contextualization of Descartes' thinking. Throughout this article we will recognize the debts with that literature which, however, has not yet managed to uproot the legendary interpretation of Cartesian thought.
} 
Thus, even if we believe Descartes' invention of mind, ${ }^{3}$ it would not be necessary to accept his alleged thesis of the autonomy of consciousness in relation to bodily and worldly acts.

To the extent that physicalism has become a "true" and all-encompassing theory, few feel inclined to subscribe to the dogma of the Ghost in the Machine ${ }^{4}$ or the profoundly antiscientific view of material and immaterial interactions. ${ }^{5}$ In fact, "Descartes' error" would involve his understanding of the body and mind as something radically different — and even opposite - rendering their interaction unintelligible. ${ }^{6}$

Certainly, Descartes was part of what we now call "new science" in contrast to influential Aristotelian scholasticism, but the lexicon and point of view of his Meditations on First Philosophy or his Principles of Philosophy remained indebted to the dominant doctrine; unanimously, the critics of his time (Hobbes, Arnauld or Gassendi, among others) understood that the scholastic notion of "substance" was central for understanding Cartesian dualism. According to this ideal interpretation, substance would be something similar to the unconscious basis of Cartesian ontology and "anthropology."7

${ }^{3}$ See Rorty, Philosophy and the Mirror of Nature, 61 and a discussion of this point of view in Sutton, Philosopby and Memory Traces, 50-55.

${ }^{4}$ See Ryle, The Concept of Mind, 5. For a critical discussion of this caricature, see Reiss, "Denying the Body?".

${ }^{5}$ See Dennett, Consciousness Explained, 33. Although the causal closure thesis underlying these platitudes is a recent empirical thesis; see Papineau, "The Causal Closure of the Physical and Naturalism".

${ }^{6}$ See Damasio, Descartes' error, 247; Williams, Descartes, 273.

7 Nietzsche understood this by denouncing the prejudice of substance, which would have passed unnoticed by Descartes's 
Thus, thought and extension would be the attributes of two distinct and irreconcilable substances (the only ones existing along with the divine): res cogitans or the mind, which is pure, indivisible, and always identical to itself and enjoys essential individuality; and the bodies in which the res extensa expresses itself, which are composed and indefinitely divisible with temporary individuality. In this sense, to conceive the subject or thinking substance and to achieve the full consciousness of the immaterial being, as Taylor noted, ${ }^{8}$ we should observe the ontological fissure: the mind must objectify our ordinary embodied perspective, disconnecting us from the world (including here another ego). The ego cogito thus emerges from hyperbolic doubt thanks to an undoubted self-knowledge that abhors the body and all other things that particularize and question it, such as biography, memory or context. $^{9}$

Can we really imagine our own disembodied existence or an existence with a body different from the one we have? As some thinkers have objected, ${ }^{10}$ such a thing may not be possible from a linguistic viewpoint, and, furthermore, such a mind would lack all our proprioceptive and exteroceptive experiences, as well as the beliefs and intentions attached to them. In addition, this hypothesis leaves many elements to be explained, such as the problem of the interaction between corporeal and mental substances, particularly its difficult link

hyperbolic caution as a transposition of the grammatical structure of subject and predicate. See Nietzsche, The Will to Power, $\int 484$.

${ }^{8}$ See Taylor, Sources of the Self, 145.

9 See Canziani, "La métaphysique et la vie", 72. Descartes is often seen in the humanities as the classic 'objectifier of nature', see Sawday, The Body Emblazoned, 29 and a critique of this kind of narrative in Snider, "Cartesian Bodies".

${ }^{10}$ See Flew, "Personal Identity and Imagination"”, 123. 
with the notion of causality, efficient, or occasional. ${ }^{11}$ Last, this position does not fit well with some current scientific advances. Relevant empirical studies, such as Damasio's somatic marker hypothesis, ${ }^{12}$ show that the more refined operations of the mind do not seem to be separated from the structure and functioning of the biological organism. In particular, so-called guttural emotions which have a clearer corporeal origin, play a relevant role in practical reasoning and in our decision making.

Thus, we continue understanding the mind in terms of the supposedly Cartesian notion as a self-contained entity, transparent to itself and only accidentally connected with external elements (including our body). However, the philosophical leanings that have woven the legend of Descartes has proven to be influential and predicts a short future for the illusion of the Cartesian consciousness.

However, we could ask whether this smear campaign corresponds to what we find in a full and complete, nonfragmentary and contextualized reading of Descartes' work. Is Cartesian thought, at this point, an idea of a subject as

${ }^{11}$ Caricatured by Ryle with the notion of para-mechanical causality (see Ryle, The Concept of Mind, 9), is partly one of the Cartesian exegesis topics known under the label of the "mind-body problem." Some scholars have argued that Descartes held that the cause must resemble the effect. If he did, there would seem to be a problem for the mind-body interaction (see, for example, Radner, "Descartes' Notion of the Union of Mind and Body", 161). On the other hand, O'Neill argues very cogently that Descartes's causal principles pose no problems for interaction in "Mind-Body Interaction and Metaphysical Consistency", 245, and Rozemond, "Descartes on Mind-Body Interaction", 436, 445, shows that Descartes does not seem particularly worried about that.

12 See Bechara, Damasio, Tranel and Damasio, "The Iowa Gambling Task", $195 \mathrm{ff}$. 
substance and an idea of consciousness as only accidentally related to a body with which it establishes a mysterious causal interaction? Is Cartesian consciousness a dispassionate ghost inserted into a cold machine? The answer to these questions in this article is going to be a resounding no, but to substantiate our answer, we will not directly object to the hypothesis of some of the main proponents of the legend (such as Ryle or Damasio). ${ }^{13}$

Instead, we suggest contextualizing Descartes' thought, placing it in his time and considering that it is closely related to the medical tradition and the advances of "new science". We also want to heed the Cartesian recommendation of reading him in a comprehensive way, ${ }^{14}$ considering works such as The Treatise on Man or The Passions of the Soul — which are usually disdained or misinterpreted - as well as part of his correspondence. Finally, we will propose a new look a Cartesian thought that, without denying dualism, heeds the unity of the vrai homme, the passionate character of the embodied mind, and its possible relation to current discussions in philosophy of the mind and cognitive sciences such as the hard problem of consciousness. ${ }^{15}$

13 Röd has already shown the biased character of Ryle's interpretation (see Röd, "Descartes' Mythus oder Ryles Mythus"), and Kirkebøen's "Descartes Embodied Psychology", among others, has revealed the shortcomings in Damasio's reading of Descartes.

14 "I would also have added a word of advice about the way to read this book. I should like the reader first of all to go quickly through the whole book like a novel (...) "(AT IX: 11/CSM I: 185). We quote Descartes following the edition of his complete works by Charles Adam and Paul Tannery (AT), and then the Cottingham, Stoothoff, Murdoch (and Kenny, vol. 3) translation (CSM/CSMK) volume and page.

${ }^{15}$ See Chalmers, "Facing Up to the Problem of Consciousness". 


\section{THE CARTESIAN BACKGROUND}

In every legend, there are real elements, and without a doubt Descartes advocated a real distinction between the immaterial mind and the material body (explicitly, for example, in AT VII: 79/CSM II: 55 but also in many other passages). However, this was not new in his time. In fact, to be fully understood, Cartesian philosophy has to be placed in the context of discussions about Christian anthropology in medieval and Renaissance scholastic thinking. ${ }^{16}$

In this debate, in which both Plato's work and the studies of Aristotle on the soul and animals were of great importance, two problems were central: the substantial unity of the person and the principle of individuation. ${ }^{17}$ The most important issue was to resolve what it is to be a man and the source of their unity, establishing their numerical and qualitative identity according to an essential dilemma: matter or form. The terms of this alternative were mainly those of the substantial form of Aristotelian scholastic hylomorphism ${ }^{18}$ and the option of Duns Scotus centered in the mind. ${ }^{19}$

It is clear that Descartes, in accordance with his critique of Aristotelianism, chose to understand the mind as a source of uniqueness, and there is a transcript of his well-known distinction between the mental and the corporeal areas.

\footnotetext{
${ }^{16}$ See Gilson, L'esprit de la Philosophie Médiévale, $194 \mathrm{ff}$.

17 See Nájera, Del ego cogito al vrai homme, 16. For a helpful discussion of the change in conception of mind and soul, see Rozemond, "The Nature of the Mind", 49-54.

${ }^{18}$ With regard to the complex notion of the Aristotelian substantial form and its scholastic reception, see the classical study of Gilson, Études sur le rôle de la pensée médiévale, $143 \mathrm{ff}$.

${ }^{19}$ See Rodis-Lewis, L'individualité selon Descartes, $55 \mathrm{ff}$.
} 
However, the cogito in its intimate structure includes modes of consciousness linked to the corporeal, such as the imagination or the senses, which from the beginning hindered the possibility of a complete self-transparency of a lonely mind:

But what then am I? A thing that thinks. What is that? A thing that doubts, understands, affirms, denies, is willing, is unwilling, and also imagines and has sensory perceptions (AT VII: 20/CSM II: 19).

Bodily opacity would thus hinder Cartesian attempts of self-knowledge, in keeping with the importance of soulsearching in the wake of the religious movements of the Reformation and Counter-Reformation. Thus, by incorporating these modes into mental phenomenology, by attempting to embrace all modalities of human experience, he left the door open to a type of subconscious avant la lettre. ${ }^{20}$

However, beyond these limitations, Cartesian dualism is linked to a polemical position towards the dominant doctrine not only in scholasticism but also in the physiology of its time. His contemporaries thought that the soul, mainly following Aristotle, was the principle of nourishment, growth, and movement of every living being (adding intellect and will in human beings), but for Descartes, the spirit,

20 See Rodis-Lewis, Le probleme de l'inconscient, 4ff. The ordinary psychological experience includes many subconscious and confused phenomena, which go against the sort of permanent consciousness required by the Cartesian cogito and Descartes himself refers to some of them, such as the dreamlike illusions of the Meditations, or secret inclinations such as those mentioned in The Passions of the Soul, when he alludes to the ambivalent emotions of the man who has been widowed (AT XI: 441/CSM I: 381). 
assimilated to the consciousness, could not be the substantial form of the body, the agency that directs all its operations.

However, to correctly understand the critical and innovative nature of the Cartesian proposal, it must be placed within the framework of a much greater transformation, which was carried out in the conception of Nature inherited from the Aristotelian magisterium. For Aristotle, the key distinction in defining the physis is to be established between external and internal causes of movement, with Nature being the principle of internal movement. ${ }^{21}$ In addition, a theoretical distinction could be made between matter and form as constituents of Nature: the natural form would be internal to the moved thing, and the tripartite soul would become the substantial form of each living being. ${ }^{22}$

However, with the advances of the "new science" and taking into account the essential contributions of Galileo or Descartes himself, among others, Nature ceased to be conceived as the internal principle of movement and began to be understood as the arena of time-space transformations of matter under universal mathematical laws. Consistent with this, the basic elements of Cartesian physics included the identification of matter with the extension and the postulation of three laws: (1) the persistence of states of matter; (2) the rectilinear tendency of the corpuscles and 3) the local conservation of the amount of movement in collisions between particles of matter (AT VII: 62-65/CSM I: 240-242). These three rules would govern the movements

\footnotetext{
${ }^{21}$ See Aristotle, The Physics, 2.1, 192b 14-15, 21-23.

22 That is, in contrast to what happens in the case of an artifact, such as a clock, whose parts are autonomous (and the resultant object is conceived as an aggregate), an animal cannot be reduced to the sum of its parts given the holistic nature of its own substantial form. See Hassing, Cartesian Psychophysics, $15 \mathrm{ff}$.
} 
and interactions of every part of matter in the plenum (for, as is well known, Descartes rejected the existence of the void) without any reference to substantial forms or final causes.

Thus, in contrast to the traditional Aristotelian scholastic conception in which matter and form are principles of a substance that are only separated verbally, Descartes would understand that hylomorphism constitutes an illusion: a mere abstraction when conceived separately, the form would not contribute to explaining how the matter informed becomes a subject of action and an object of passion. ${ }^{23}$

Thus, forms were no longer conceived as causes and principles of Nature. The soul would cease to be the general biological principle of vital warmth and movement, and these functions would be brought back to the mechanism of the body, whose parts would be subject to the same laws as the rest of the physical world. In addition, the spirit would come to be understood as consciousness or mind, also rejecting the traditional hierarchical division of parts of the soul - a higher one devoted to reasoning and others that are lower and centered in the emotional and appetitive side. ${ }^{24}$

${ }^{23}$ Gilson, Études sur le rôle de la pensée médiévale, 163. In contrast, Paul Hoffman and Justin Skirry argue that the Cartesian human being is an Aristotelian hylomorphic substance (see Hoffman, "The Unity of Man" and "Descartes's Theory of Distinction"; Skirry, Descartes and the Metaphysics of Human Nature). This is a version of the famous trialist or "third substance" reading, due to Cottingham's, although his original article is very cautious in restrictring Descartes' notion to a weaker attribute trialism (Cottingham, "Cartesian Trialism", 229). On the other hand, Nolan, "Cartesian Trialism on Trial", 152 and 157-158, argues powerfully against this kind of proposals.

${ }^{24}$ Aristotle, The Nicomachean Ethics, 1.13, 1102a27-1103a10; 3.12, 1119b13. This distinction goes back to at least Plato, Republic, IV $435 \mathrm{c}, 441 \mathrm{c}$, and is linked to a pre-modern ethical-political understanding, which needed the hierarchy of the soul to justify civic subordination. In contrast, the modern ego would be 
Finally, thought would no longer be understood as a holistic principle and is instead now placed inside the brain at the pineal gland, with whose bodily movements it would establish relations of mutual affection or association (AT XI: 129/CSM I: 100; AT XI: 351-353/CSM I: 340).

Thus, Descartes is credited as virtually the first to initiate a micro-mechanical approach to physiology. ${ }^{25}$ In line with what has just been discussed, his purpose would have been to transform all the functions in the body traditionally assigned to the sensory and vegetative soul, reducing consciousness and its modes to its mental dimension.

Although the medicine of his time, predominantly Galenic (and ultimately Aristotelian), greatly influenced Descartes, ${ }^{26}$ it cannot be said that his anatomical and

undifferentiated, without any reference to such heterogeneous and stratified parts (AT XI: 364-366, 379/CSM I: 345-346, 352-353).

${ }^{25}$ It is important to note that, as Hatfield points out in 'Descartes' Physiology", 338-339, both physiology, a term barely used by Descartes, and psychology (which he never mentions, although the notion had already been developed in the sixteenth century) have a different sense from what we understand nowadays. In the first case, physiology refers to the part of medicine that explains the nature of the human body by applying the Aristotelian theory of nature in general (and specifically refers to the Galenic doctrine of the four humors, whose balance guarantees human health). In the second case, psychology pertains to the topic of the soul, as it was mainly formulated in Aristotle's De anima and Parva naturalia.

${ }^{26}$ For example, the persistence of the humoral theory in the Cartesian writings when referring to Elisabeth, princess of Bohemia, showed his opinion on the different temperaments (AT IV: 311/CSMK: 271). Although the humors would not be causal principles but a consequence of the movements of the finer matter in his case, animal spirit (again, a Galenic inheritance as Temkin, Galenism, 100-107, explains), like the subtler parts of the blood, 
experimental studies gave rise to suitable descriptions in general terms; ${ }^{27}$ doubtlessly, his iatromechanical perspective allowed him to transform the inherited conception of the body. Accordingly, where previous physiologists had invoked incorporeal powers, faculties, or agents, to offer explanations of living things, Descartes only appealed to matter in motion, organized as a machine whose pieces fitted perfectly (in contrast with the holism of the Aristotelian form) and function automatically: 28

reach the concavities of the brain and alter or reinforce machine behaviors.

27 An example of this would be the polemic against the physician William Harvey about the movements of the heart, which Descartes mistakenly considered to be non-muscular (AT XI: 169170; AT VI: 50/CSM I: 136). However, the familiarity of the thinker with the main medical texts of his time is evident because he mentions the most relevant anatomists and physiologists in various places such as Galen, Fernel, Harvey, Bartholin, Bauhin or Fabricius, among others, and asserts that he do not wish to propose anything that would cause controversy with the discoveries and central hypotheses of these authors (AT I: 378/CSMK: 59). Finally, the interest of Descartes in the dissection and direct observation of animal corpses is also explicit, as evidenced by the famous anecdote narrated by Baillet, his first biographer. An scholar visited the thinker in his home, and when Descartes was asked about his books, the visitor was taken to the backyard, where Descartes showed him a calf that he was dissecting and pointing to it: "Here is my library" (see Baillet, $\mathrm{La}$ vie de Monsieur Descartes).

${ }^{28}$ According to the classic presentation of Canguilhem, La formation du concept de réflexe, 30, 33, without any reference to reflexive movement, though other scholars inscribe Cartesian neurophysiology in a more complex narrative and challenge his polemic account (Sutton, "The Body and the Brain", 708).

Manuscrito - Rev. Int. Fil. Campinas, v. 43, n. 2, pp. 54-94, Abr.Jun. 2020. 
I should like you to consider that these functions follow from the mere arrangement of the machine's organs every bit as naturally as the movements of a clock or other automaton follow from the arrangement of its counterweights and wheels. To explain these functions, then, it is no necessary to conceive of this machine as having any vegetative or sensitive soul or other principle of movement and life (...)(AT XI: 202/CSM I: 108).

In addition, by modifying the conception of the body, Descartes also altered its relationship with mental states. Here, although Descartes' ideas may be considered in many senses a precedent for neuro-anatomical studies such as those carried out by Damasio, ${ }^{29}$ he was not a reductivist because he considered the existence of mental experiences, the reality of a consciousness that accompanies and interprets the body movements of the mechanism to which it is inextricably linked, undeniable. However, to account for this point, we must go to the next section and consider the emotions of the embodied mind.

\section{THE TRUE MAN AS A SUbSTRATUM OF PASSION}

Regarding passion in the work of Descartes, two elements are usually held that are different and, at least initially, contradictory. On the one hand, we are told that the

${ }^{29}$ Obviously, neither Descartes nor any of his contemporaries were aware of the neurochemical connections between the brain and the rest of the body, which, like many other elements, are now part of neuroscientific theory. See Brown, Descartes and the Passionate Mind, 62. 
French thinker was scarcely original ${ }^{30}$ and that his supposed invitation to dominate the passions of the soul by reason had a clear rootedness in a tradition beginning with Plato and passing through Aristotle, ending in the Stoic moral. On the other hand, we are told that Descartes would have substituted the moralistic rhetoric of his predecessors with a mechanistic doctrine, leaving aside the teachings of Aristotle and post-Aristotelian thinkers and presenting a sort of reductionist cognitivism in his conception of emotions. ${ }^{31} \mathrm{In}$ short, this contradiction would reveal the last-minute character of Descartes' physiological and moral reflections.

However, the former can be fair. Although Descartes' later works propose a therapy for passion and insist on moderation and indirect control, as we shall see below, their aim can hardly be linked to the Stoic ideal of elimination of passion, since Descartes considers passion an error of judgment. Although it is true that Descartes himself claims that he wants to explain passion "only as a natural philosopher, and not as a rhetorician or even as a moral philosopher" (AT XI: 326/CSM I: 327), this restriction literally reiterates a thesis of Aristotle: "This at once makes it the business of the natural philosopher to inquire into the soul (...)".32 It is also clear to any reader of The Passions that Descartes does not limit himself to describing these ideas in the same terms as a physiologist but instead links it to a phenomenological and moral study. ${ }^{33}$

30 See Taylor, Sources of the Self, 148.

31 See Solomon, "On emotions and Judgements", 183; Greenspan, Emotions and Reasons, 3.

32 Aristotle, On the Soul, I.1, $403 \mathrm{a} 28$.

33 See Kambouchner, L'Homme des passions, vol. I, 91, 94-95. In a recent paper on the mind-body union, Koivuniemi and Curley also place great importance on internal-sense phenomenology for 
Thus, although the French author is not fully original in his approach and cannot even be considered a pioneer in regard to combining and synthesizing two previous approaches to the passions, the medical and moral (as Galen, Avicenna or Thomas of Aquinas, among others, had done before), his proposal is significantly different and much more elaborate than what is normally assumed by those who hold the Cartesian legend. However, to make it clear, we must pay more attention to the passion context in which the Cartesian project unfolded.

In that sense, we can begin by pointing out that the two main moral traditions prevailing in the seventeenth century were the Aristotelian and Stoic traditions. ${ }^{34}$ The prestige and influence of Aristotle was undoubtedly still significant at this time, but his evaluation of passion, which is basically positive, contrasted with the Christian atmosphere, which linked passion to original sin and the fall of man. Christian doctrine claims that emotions must be controlled strictly by reason and will; therefore, the intellectualist conception of Stoicism, with its ideal of rational mastery, was gaining greater prominence.

Stoics believed that emotions were linked to evaluative judgments that, by their tendency to exaggerate the importance of the self, were false and vicious. It was thus

Descartes' account of the mind-body union ("Descartes on the Mind-Body Union", 91-93) and Simmons, "Mind-Body Union and the Limits of Cartesian Metaphysics", 25ff, too. See, also, James, Passion and Action, 87ff and Brown, "Passion", 563ff in order to properly frame the significance of passions in Cartesian thought.

${ }^{34}$ Levi, French Moralists, 26; James, Passion and Action, 90. The latter is a very relevant work for understanding the framework in which Descartes is situated, since, as she herself points out, "cartographies of early-modern philosophy have tended to leave out the passions of the soul" (James, Passion and Action, 16).

Manuscrito - Rev. Int. Fil. Campinas, v. 43, n. 2, pp. 54-94, Abr.-Jun. 2020. 
desirable and possible to achieve a state of complete liberation and elimination of bodily passions (apatheia) or at least of its evaluative dimension (since the Stoics admitted the existence of certain preliminary passions (propatheiai) or involuntary movements linked to them are uncontrollable even to the wise). ${ }^{35}$

Descartes recognized the importance of reason in distinguishing what falls under our control and what does not, but in terms of regulating desires in accordance to reason (AT IV: 264/CSMK: 257; AT XI: 436-440/CSM I: 379-381), he could not agree with Stoic intellectualism or its ideal of the dispassionate wise: "(...) I am not one of those cruel philosophers who pretend that the wise man must be insensitive" (AT IV: 201-202). By assimilating passion to the Stoic preliminary passion to a certain extent and by considering (as the first part of The Passions of the Soul shows) the body's mechanical dimension, the French thinker rejected the possibility of direct control of these areas.

Passion certainly had a mental component for Descartes, and he believed it was possible to influence passion - hence the therapeutic character of the Cartesian proposal and its moral dimension. However, to moderate passion one has to account for the involuntary bodily element, the automatic reaction of the machine to the stimuli of the external world, or the influence of certain patterns of corporeal memory that are fixed in the brain by the animal spirit, which fights against our conscious will and, in many cases, dominates it.

In any case, let us insist that it is possible, and this is what the Cartesian proposal is about: indirect control of the

35 See Knuuttila, Emotions in Ancient and Medieval Philosophy, 76-78. On that subject, Inwood, Ethics and Human Action in Early Stoicism, 175ff; Inwood, "Seneca and Psychological Dualism", 164ff, as well as a classic source, among others, Seneca, On Anger, II, 2, 1 and II, 3,4 . 
passions that bind us (and which unleash somatic-psychic conflicts, sometimes of great severity and terrible consequences) through the development of attention and certain habits. ${ }^{36}$ These can give rise to other passions, attenuating those that are harmful to us and contributing, in short, to strengthening those that benefit us (although he indicates to Chanut in a letter dated November 1, 1646, "I have found almost all of them to be good" (AT IV: 538/CSMK: 300), its misuse can become harmful (AT XI: 485-488/CSM I: 370-371)). ${ }^{37}$

36 Against the assumption of many commentators, who in the wake
of Margaret Wilson's theory of the "Natural Institution" (Wilson,
Descartes, 207-220) think that the associations between states of
mind and body are fixed by God, Descartes maintains that we can
reform them, and this is very important for his account of the
mind-body relationships (see Shapiro, "Descartes' Passions of the
Soul', 212ff).
37 An example of this can be seen in another letter to Chanut, dated
June 6,1647 , in which he discussed his childhood passion for a
cross-eyed girl, a love that became stable and unconscious in a sort
of emotional memory: "(..) for a long time afterwards when I saw
persons with a squint, I felt a special inclination to love them
simply because they had that defect. At that time, I did not know
that was the reason for my love; and indeed, as soon as I reflected
on it and recognized that it was a defect, I was no longer affected
by it." (AT V: $57 /$ CSMK: 322 ). It is interesting to note how, despite
its many deficiencies in the anatomical description, the Cartesian
hypothesis anticipates some central points of current psychological
theses about the link between attention and emotions; see LeDoux,
The Emotional Brain, $284 f f$. In addition, it is noteworthy that the
"scientific" mechanism underlying this phenomenon is first set out
in Treatise on Man, when Descartes talk about the cloth metaphor
for accidental but inertially persistent concomitance (AT XI: $178-$
179 ). In that sense, it places a "scientific" hypothesis under a class
of problematic human phenomena, generally irrational attractions
and phobias. It thereby comports with Descartes' therapeutic Manuscrito - Rev. Int. Fil. Campinas, v. 43, n. 2, pp. 54-94, Abr.-Jun. 2020. 
In the same sense, it can be said that the passions also reintroduce the teleological dimension, denied in the Cartesian mechanistic physical system. Although, according to the Aristotelian theoretical framework, life's preservation, for which the divinity instituted the passions first (AT VII: 83/CSM II: 57), is at the lowest level, this is undoubtedly an end and explains the general goodness of emotions. Thus, against Stoic recommendations, passion is seen by Descartes from a genetic perspective as a bodily-mental resource that from early childhood guarantees our health and the care of our bodies and is able to go even further until we are brought to a full inversion of that basic teleology, when love or generosity demand an extreme sacrifice (AT IV: 293294/CSMK: 266).38

What are passions for Descartes specifically? It is difficult to explain clear and distinctly, considering their dual dimension of mental and corporeal, ${ }^{39}$ but it can be said that they are ideas or perceptions (in the Cartesian sense of "idea" according to the definition given in his answers to the Second Objections to Meditations on First Philosophy (AT VII: 160-161/CSM II: 113): not images of the imagination but modifications or contents of the pure mind), caused in the mind by the body, in the body as a result of the movements of the animal spirit, or generated by the same mind, modifying the body dispositions (since the relation is biconditional or non-compulsive between the organism and

intention. See Hassing, Cartesian Psychophysics, 41-45. I would like to thank the anonymous referees for that last reference.

38 On the problem of the return of teleology in the Cartesian description of living bodies and the charge of inconsistency see Shapiro, "Health of the Body-Machine", 424, 435 and Des Chene, Spirits \& Clocks, $125 \mathrm{ff}$.

39 See Kambouchner, L'Homme des passions, vol II, 325. 
consciousness). In that sense, they adhere to the spirit and are "felt" in the mind but clearly come from "elsewhere", from what is not consciousness, although they can move it as no other thought does (and in that sense, we also call them emotions (AT XI: 349-350/CSM II: 338-339)). ${ }^{40}$ To sum up, while from a physiological point of view a passion is a corporeal impulse of the animal body (AT V: 278/CSMK: 366), from a psychophysical perspective, "passions of the soul" are modes of the soul that "depend absolutely" on actions of the body (AT XI: 359/CSM I: 343). So, in that last sense, the passively caused passions move the mind. ${ }^{41}$

The key question, then, is what concrete roles the body and mind play in the passionate dimension of the human

40 It is therefore appropriate to disagree with the cognitivist conception of emotions that can be found in various studies of the Cartesian passions, such as Williston, "The Cartesian Sage", 310311, and consider the approaches of other perspectives such as Prinz, Gut Reactions; Prinz, "Which emotions are basic?", 69ff. For this author, who significantly ignores the Cartesian contribution, emotions are linked with bodily changes on the one hand, according to the classic hypothesis of William James and Carl Lange. On the other hand, they are related to the phenomenological dimension of these changes, the conscious or mental aspect (we do not run because the heart beats quickly but because the increase in the speed of our pulse is interpreted as a danger sign and is linked to the detection of a potential threat in our environment). If, according to Prinz's theory — which he calls "embodied appraisal" - that emotions are embodied because they turn out to be perceptions of bodily changes and appraisals are embodied because they represent an interesting matter to the agent, Descartes would be a clear precedent of that position.

${ }^{41}$ See Brown and Normore, "Traces of the Body", 83ff; Alanen, "The Intentionality of Cartesian Emotions", 107ff and Rorty, "Descartes on Thinking with the Body", 380, who focuses on the informative and motivational function of the Cartesian passions. 
being. If the body is the general cause of passions, it would seem that the mind must be a mere spectator, although we have already questioned their merely representational or cognitive characterization. If the mind is active, its purity would be questioned, and one could consider both the rationality of the mental sphere and the reality of the bodymind distinction, eminently postulated in the metaphysical writings of the French thinker.

This is a complex question, which, in essence, considers the reality of the union in the human being and its coherence with the Cartesian real distinction. However, as some authors have noted, ${ }^{42}$ Descartes tried to consider the passivity of the sensations (internal and external) and the passions as a full mode of the res cogitans mainly during the last period of his life. That is to say, although we indicated that the experiential modalities related to the body already appeared in the Meditations on First Philosophy (with the ego as a thing that thinks, wants, imagines and feels), it is in his late correspondence and his last work where Descartes thinks in more detail about the imagination and the emotions as modalities of the mind that necessarily need the body to be developed.

Thus, in contrast to Aristotle, where action and passion were two mutually combinable categories ${ }^{43}$ because they referred to one being whose formal and material principles were merely verbal, in the case of Descartes, this combination, while also possible, would take place between different but mutually responsive elements (AT XI: 327-

${ }^{42}$ Marion, Sur la pensée passive de Descartes, 23-24.

${ }^{43}$ See Aristotle, Categories, 4 and 9. Indeed, in Aristotle action and passion refer to a single ousia, whose unique enérgeia put in action, thus instead of a relationship between heterogeneous elements, action and passion, what the Stagirite raises is a deep identity thanks to the enérgeia that brings them together. 
328/CSM I: 327; AT III: 428/CSMK: 193). In the case of passion, then, we speak of a mode of consciousness by means of which the res cogitans would be considered passively without exercising the cause of his own thought in a "general" way or being merely a spectator of their emotions. ${ }^{44}$

The mode of pure intellection, the intellect as the function of our mind, does not suffer or become impassioned in any way, and inert bodies, pure extension, would not have that discernible facet. We are one with our body because we suffer and we are passionate, according to Descartes, thanks to the passivity mode through corporality. Our flesh feels everything while feeling itself at the same time, and our mind does not experience sensations without the bodily medium acting on our passively understood consciousness.

Keeping this in mind and taking a well-known letter to Mesland of February 9, 1645 (AT IV: 172-175/CSMK: 241244) as a starting point, where the thinker distinguishes bodies in general from the body of a human being, some authors have proposed an idea of individual as corporeal subjectivity in Descartes. ${ }^{45}$ Certainly one might point to a sort of ambiguity in his treatment of bodies since, at least in Meditation VI, external bodies are doubtful and their principle of unity is only contingent, in the case of our flesh, on the notion that my body is myself, and its undoubted unity is determined by the consciousness closely linked to it. If I were not united to my body, I would not fully develop all the modes of the human mind, including that of the imagination, which allows me to think about other bodies, which are not mine and are not myself:

${ }^{44}$ Marion, Sur la pensée passive de Descartes, 224-225.

45 See Azouvi, "La formation de l'individu", 264. 
First of all, then, I perceived by my senses that I had a head, hands, feet and other limbs making up the body, which I regarded as part of myself, or perhaps even as my whole self. I also perceived by my senses that this body was situated among many other bodies (...) (AT VII: 74/CSM II: 51-52).

In fact, in contrast to the ontological criterion that allowed, on the real distinction level, to separate bodies, which are indefinitely divisible, from the mind without parts in the case of the true man, the substrate of all passions, ${ }^{46}$ the spirit remains essentially indivisible, but our body and our flesh are also functionally indivisible (as Descartes notes, by virtue of the disposition of the organs, whereby "the removal of any of them renders the whole body defective" (AT XI: 351/CSM I: 339)). ${ }^{47}$ The passionate body acts as a whole that affects the mind, and it unfolds itself in its own modes through the body and as a body that is passively affected. Both can be conceived but not experienced separately. 48

\footnotetext{
${ }^{46}$ We follow Marion's recommendation (See, Marion, "Descartes no sujeto", 113) here. He understands that the characterization of Cartesian thought as a philosophy of subjectivity and the attribution of the modern concept of subject to him is abusive and unacceptable in light of the terminology and notions employed by Descartes, who never spoke of this subject except in terms of substrate or bypokeimenon.

${ }^{47}$ See Pavesi, La moral metafísica, 57, 120.

48 See Alanen, Descartes's Concept of Mind, 72-77, who understands the mind-body union as a domain of practical knowledge only, and
} 


\section{THE EMBODIED MIND AND THE HUMAN WORLD}

Gassendi was the first to make an objection that would foreshadow many others, such as Damasio's:

And if you are something separate, how are you compounded with matter so as to make up a unity? Moreover, since all compounding, conjunction or union takes place between the component parts, must there not be some relationship between these parts? Yet what relationship can possibly be understood to exist between corporeal and incorporeal parts? (AT VII: 344/CSM II: 238).

The Cartesian answer, which at the time was not convincing or, rather, did not seem to be an answer at all, consisted of the mere reiteration of something to which we must attend in this last section of the text because it will allow us to understand the specific status of being a passionate human, as Descartes seemed to conceive it, in the context of his time and his writings.

For the French thinker, the bond or interlacing between my body and my mind does not belong to the order of relations that are established between two extended bodies whose corpuscles collide and causally bind (in this sense, the categorical error which Ryle attributes to Descartes would simply be an interpretative error of the Anglo-Saxon author). This certainly agrees with the Cartesian concept of mechanical causality: causal relationships are a function of

Simmons, "Mind-Body Union and the Limits of Cartesian Metaphysics", in a similar vein.

Manuscrito - Rev. Int. Fil. Campinas, v. 43, n. 2, pp. 54-94, Abr.-Jun. 2020. 
the extension of bodies and the mind is a thinking and unextended thing. ${ }^{49}$

In this direction, the multiple analogies that Descartes sets out to show are presented with difficulty, probably due to the lack of an appropriate lexicon, whose description is adequate to give an account of the authentic human being. Additionally, this or the supposed Cartesian explanation, does nothing to establish an accidental connection between diverse substances, as is usually perceived.

Thus, the analogy of the pilot in his vessel negatively expresses how the mind is closely linked to the body and is mixed (permixtio) with it:

(...) I am not merely present in my body as a sailor is present in a ship, but that I am closely joined and, as it were, intermingled with it, so that I and the body form a unit. If this were not so, I, who am nothing but a thinking thing, would not feel pain when the body was hurt but would perceive the damage purely by the intellect, just as a sailor perceives by sight if anything in his ship is broken. Similarly, when the body needed food or drink, I should have an explicit understanding of the fact instead of having confused sensations of hunger and thirst (AT VII: 81/CSM II: 56). ${ }^{50}$

${ }^{49}$ Richardson, “The 'Scandal”, 24.

${ }^{50}$ The importance of this analogy testifies that it had already been more succinctly stated in the Discourse on the Method (AT VI, 59/CSM I, 141) referring to the true man. On the origin and history of this metaphor, which in the scholastic tradition was used to contrast Plato with Aristotle, see the work of Manzini, "Comme un pilote en son navire", $163 \mathrm{ff}$. 
The meaning of the metaphor is clear: although a pilot has greater knowledge and control of his ship than a common sailor or a simple passenger, the experience of their union is not so intimate as to feel pain when a part breaks down. In this sense, while the link between the pilot and the ship is accidental, the same is not true of the mind-body relationship, which is originally established in an essential and inseparable way.

Other analogies appear to be along the same lines, such as the gravity analogy, which we find in a correspondence with Elisabeth, Princess of Bohemia (in the epistle of May 21, 1643), as well as in the Sixth Replies to her Meditations in a letter to Regius of January 1642, in a letter to father Dinet, and in a letter to Arnauld of July 29, 1648, ${ }^{51}$ which question the application of causal relationships in the field of the union, proposing in its place a sort of "action at a distance". There is also the analogy of the plumber (AT XI: 131132/CSM I: 100-101) or that of the arm and the rest of the body (AT VII: 228/CSM II: 160) or the metaphor of the relationship between bones and flesh (AT VII: 423/CSM II: 286).

In short, and although each analogy illuminates a different aspect of the description that Descartes considers correct, it is possible to note as the main result of these metaphors that the mind does not use the body as an object that is alien to it, unlike what it happens in the case of a pilot with his ship or in an angel: "Additionally, I thought I was careful to guard against anyone inferring from this that man was simply 'a soul which makes use of a body"' (AT VII:

\footnotetext{
${ }^{51}$ See Llinàs, "La integración", 45, for the complete references of these letters.
} 
227/CSM II: 160). What comes first is the consciousness of unity. 52

The restlessness that arises here that is at the basis of the aforementioned Gassendi's objection that would be repeated by many thinkers, such as Kant, ${ }^{33}$ is how to establish a real distinction between two substances, with the attributes of thought and extension, at the same time as the true union that constitutes the real human being (particularly when we do not find that substantial self, as the aforementioned Kant or Hume noted, in our thinking). However, as some scholars have noted ${ }^{54}$ there is no need to conceive the ego cogito as a substance: after all, its permanence is only that of an act of thinking, lacking the duration in time and the immutability that is supposed in a substance, except by the ordinary contribution of God. 55

Indeed, although substance has a relevant role in Meditations regarding the existence of God and in relation to extended bodies, as far as to mind is concerned, only divine intervention allows us to speak of a substantial finite entity. Thus, if we carefully consider the Aristotelian-scholastic notion of substance as an entity that exists by itself, it must be admitted that it would hardly be applied in the Cartesian case to the ego or consciousness.

This is where the third primitive notion that Descartes expounded to Princess Elisabeth in their correspondence

52 Although there are a few commentators who have charged Descartes with a sort of "angelism" like Voss, "Descartes: The End of Anthropology", 274.

${ }^{53}$ Kant, Critique of Pure Reason, A 350-351.

${ }^{54}$ See Marion, Sur le prisme metaphysique, 164.

${ }^{55}$ Perhaps more than a rejection of the notion of substance, we can speak of a redefinition, as the correspondence with Regius shows, especially the letter of January 1642 (AT III, 492/CSMK: 205). 
(AT III: 690ff/CSMK: 226ff) would come into play. As it is well known, these notions - the mind, body and the union of both - constitute a new way of referring to the simple natures of the Rules for the Direction of the Mind (AT X: $381 \mathrm{ff}$, 392ff, 410ff/CSM I: $21 \mathrm{ff}, 28 \mathrm{ff}, 39 \mathrm{ff}$ ) and the simple notions that make up our thoughts in the Principles of Philosophy (AT VIII: 22-24/CSM I: 208-209). ${ }^{56}$ However, in short, the most important idea is that they form the simplest and easiest elements to know from our epistemic perspective and, therefore, they are the patterns from which we elaborate the rest of our knowledge.

Thus, instead of thinking in terms of an extrinsic, causal relationship between irreconcilable substances (ontologically speaking), it is possible to approach this linkage from an epistemic perspective, which considers the primitive character of the union that is conceived from the starting point of our intellectual capacities and is not explained by virtue of the composition or interaction of more basic elements in a derivative way.

Although the ontological question must be raised, instead of a duality in this case, we can talk about a three-way relationship - first, with the mind as a thinking, active entity (with the modes of understanding and will); then with the extended bodies, which are knowable by the imagination and whose unity resides in an external, contingent principle; and finally, with the experience of my body as passively thinking flesh, where the union of the mind with its modalities of imagination, sensation and passion are inextricably linked with corporeality, whose principle of essential unity is the indivisible mind, and which guarantees and at the same time

56 This shows that Machamer and McGuire's main thesis, in Descartes's Changing Mind, on the evolution from an earlier Cartesian dualism to late Cartesian monism must be nuanced.

Manuscrito - Rev. Int. Fil. Campinas, v. 43, n. 2, pp. 54-94, Abr.-Jun. 2020. 
sustains itself thanks to the functional unity of the organism. ${ }^{57}$

How can we manage that distinction? The fact is that although it is asserted in the theoretical dimension, with special clarity in the Meditations as well as in the answers to the objections of his critics, only occasionally do we find a text of Descartes in which the thinker affirms the reality of a reflection and an affective function independent of the union between spirit and body: "All these movements of the will that constitute love, joy, sadness and desire, insofar as they are rational thoughts and not passions, could exist in our soul even if it had no body" (AT IV: 602/CSMK: 306). However, this conceptual piece is not repeated, and, in a consistent and orthodox way, Descartes refers continuously to divine omnipotence as a guarantor, incomprehensible to the human intellect but effective for the believer regarding the possible existence of spirit separated from the body - that is, of the immortality of the human soul or of the subsistence of other spiritual powers, like angels. ${ }^{58}$

It can be concluded, therefore, that although Descartes experiences significant difficulties in abandoning Aristotelian scholastic language ${ }^{59}$ and his attempts to elaborate new

57 Gueroult, Descartes selon l'ordre des raisons, vol. II, 186ff. See also Simmons, "Re-Humanizing Descartes", 57 and Brown, "The Sixth Meditation: Descartes and the Embodied Self', 245.

58 As he explicitly acknowledges in his conversation with Burman: "we hardly know the angels" because their knowledge, which of the existence of purely spiritual entities, is forbidden to us, inasmuch as "we ignore all that is usually investigated about them" (AT V: 157) and the same thing happens in any similar matter, such as that of our immortality, which transcends the philosophical limits.

59 And sometimes he states that his employment or admission is necessary for strategic reasons, as suggested to Regius in the letter

Manuscrito - Rev. Int. Fil. Campinas, v. 43, n. 2, pp. 54-94, Abr.-Jun. 2020. 
concepts (such as that of primitive notions) suffer from limitations, his proposal conceives of the true human being as an embodied mind, at least in the realm of life, in the practical dimension. If at the moment of theoretical and metaphysical reflection it is possible to conceive clearly and distinctly of the mind and body separately, such a distinction does not necessarily rest on a substantial dualism, and in that sense, there is no guarantee of existence or subsistence beyond thought, unless divinity allows it, but it escapes our philosophical, rational, understanding.

\section{ConClusion}

This comprehensive study of Cartesian thought, placed in its historical context and maintaining a panoramic view of his written work, allows us, at least in the realm of passion and the thorny problem of the mind-body relationship, to accept the ironic complaint that he once shared with his correspondent Chanut: "A certain Father Bourdin thought he had good reason to accuse me of being a sceptic, because I refuted the sceptics; and a certain minister tried to argue that I was an atheist, without giving any reason other than the fact that I tried to prove the existence of God" (AT IV: 536/CSMK: 299).

Without a doubt, the readings that gave rise to the Cartesian legend are due to a systematic interpretive bad faith, which attempted to discredit a complex thought by means of a decontextualizing and fragmented hermeneutic. However, our interpretation has not only challenged the

of January 1642, in which he reproaches his pointless and dangerous polemic about the notion of substantial form, which he simply avoids in his essays (AT III: 492/CSMK: 205). On the Utrecht controversy see Verbeek, Descartes and the Dutch, chapter 2.

Manuscrito - Rev. Int. Fil. Campinas, v. 43, n. 2, pp. 54-94, Abr.-Jun. 2020. 
popular radical dualist view (still present in the academic sphere, as evidenced by the references to Ryle and Damasio) but has also attempted to reveal, even partially, its tremendous actuality under a more careful reading.

As we indicated at the end of our introduction, the problem of consciousness, as a specific aspect of the question concerning the link between mind and body, is one of the most commonly addressed issues by philosophy from the mid-twentieth century to the present day. We recognize ourselves as conscious beings who feel, smell, taste, see and hear and who are moved to tears or laughter, but we do not know well what these feelings and emotions are.

The eminent philosopher David J. Chalmers dedicated his work, The Conscious Mind, to consider this subjective experience. There, the author considers that the great majority of our mental notions possess a dual nature - a phenomenal or experiential dimension and a psychological, causal dimension. ${ }^{60}$ While the second can be approached from the perspective of the cognitive science, the first, especially the domain of consciousness or subjective experience, is more difficult to address, since requires philosophical elucidation and engagement with epistemic and ontological questions in need of conceptual and nonexperimental analysis.

In this article, we have shown that Descartes, on the one hand, against his black legend, was deeply interested in the anatomical and psychological aspects of organisms in general and in the human brain in particular. In fact, as demonstrated, he was attracted by the scientific, observational dimension of the human machine of his time. On the other hand, in line with certain research of the last decades, we have explain Descartes' interest on the conceptual study of the mind and the emotions, highlighting

${ }^{60}$ See Chalmers, The Conscious Mind, 17. 
his phenomenological perspective with the investigation of an inexhaustible experiential part of the passionate human being: the embodied mind.

In short, and without delving into a parallelism that conceptual and historical distances speak from, we have emphasized a re-reading of the body's role in Cartesian thought as diametrically different from the legendary Descartes that the tradition has presented to us. Italo Calvino said in a text that became an instant classic from the moment of its publication that "a classic is a book that never finishes saying what it has to say". ${ }^{61}$ We could replicate this assertion by saying that the passionate Descartes of the anatomical studies, the adventurous mechanistic hypotheses, and the risky metaphysical and psychological theses (which both distinguishes and associates science and philosophy) still has much to tell us. His actuality does not come from the (scarce) success in the specific details but from an undeniable fact despite its legend: the questions that Descartes raised and the perspective from which he formulated them remain, in some measure, ours.

\section{REFERENCES}

Alanen, Lili. Descartes' Concept of Mind. Cambridge, MA: Harvard University Press, 2003.

. "The Intentionality of Cartesian Emotions". In Passion and Virtue in Descartes, edited by Byron Williston and André Gombay (107-127). Amherst, New York: Humanity Books, 2003.

Aristotle. Categories. On Interpretation. Prior Analytics. Edited and translated by Harold P. Cooke and Hugh

${ }^{61}$ Calvino, Por qué leer a los clásicos, 15.

Manuscrito - Rev. Int. Fil. Campinas, v. 43, n. 2, pp. 54-94, Abr.-Jun. 2020. 
Tredennick. Cambridge, Massachusetts: Harvard University Press, 1938. [Categories] . On the Soul. Parva Naturalia. On Breath. Edited and translated by Walter S. Hett. Cambridge, Massachusetts: Harvard University Press, 1957a. [On the Soul

. The Physics, Books I-IV. Edited and translated by Philip H. Wicksteed. Cambridge, Massachusetts: Harvard University Press, 1957b. [The Physics] . The Nicomachean Ethics. Edited and translated by Lesley Brown and David Ross. Oxford: Oxford University Press, 2009.

Azouvi, François. "La formation de l'individu comme sujet corporel à partir de Descartes". In L'individu dans la pensée moderne (XVIe-XVIIe siècles), edited by Gian M. Cazzaniga and Yves-Charles Zarka (259-270). Pisa: Edizioni ETS, 1995. ["La formation de l'individu"]

Baillet, Adrien and De La Monnoye, Bernard. La vie de Monsieur Descartes: Suivi de Abrégé de la vie de M. Baillet. Paris: Editions des Equateurs, 2012. [La vie de Monsieur Descartes]

Bechara, Antoine; Damasio, Hanna; Tranel, Daniela; and Damasio, Antonio R. "The Iowa Gambling Task and the Somatic Marker Hypothesis: Some Questions and Answers". Trends in Cognitive Sciences 9/4 (2005): 159162. [“The Iowa Gambling Task"]

Boghossian, Paul. "Content and self-knowledge." In Externalism and Self-Knowledge, edited by Peter Ludlow and Norah Martin (149-173). Stanford: CSLI Publications, 1998. 
Brown, Deborah J. Descartes and the Passionate Mind. Cambridge: Cambridge University Press, 2006.

. "The Sixth Meditation: Descartes and the Embodied Self'. In The Cambridge Companion to Descartes' Meditations, edited by David Cunning (240257). Cambridge: Cambridge University Press, 2014. "Passion". In The Cambridge Descartes Lexicon, edited by Lawrence Nolan (563-569). Cambridge: Cambridge University Press, 2016.

Brown, Deborah J. and Normore, Calvin. "Traces of the Body: Descartes on the Passions of the Soul". In Passion and Virtue in Descartes, edited by Byron Williston and André Gombay (83-106). Amherst, New York: Humanity Books, 2003. [“Traces of the Body"]

Canguilhem, Georges. La formation du concept de réflexe aux XVTIe et XVIIIe siècles. Paris: Vrin, 1994. [La formation du concept de réflexe]

Calvino, Italo. Por qué leer a los clásicos. Translated by Aurora Bernárdez. Madrid: Siruela, 2009.

Canziani, Guido. "La métaphysique et la vie. Le sujet psychosomatique chez Descartes". In Descartes et la question du sujet, edited by Kim Sang Ong-Van-Cung (67-91). Paris: Presses universitaires de France, 1999. ["La métaphysique et la vie"]

Chalmers, David J. "Facing Up to the Problem of Consciousness". Journal of Consciousness Studies 2/3 (1995): 200-219.

. The Conscious Mind. In Search of a Fundamental Theory. Oxford: Oxford University Press, 1996. [The Conscious Mind] 
Churchland, Paul. Matter and Consciousness, revised edition. Cambridge: Massachusetts Institution of Technology, 1988.

Cottingham, John. "Cartesian Trialism". Mind 94 (1985): 218-230.

Damasio, Antonio R. Descartes' error. Emotion, Reason, and the Human Brain. New York: Avon Books, 1995. [Descartes' error]

Dennett, Daniel C. Consciousness Explained. New York: Penguin, 1991.

Des Chene, Dennis. Spirits \& Clocks: Machine \& Organism in Descartes. Ithaca, NY; Oxford: Cornell University Press, 2001. ["Spirits \& Clocks"]

Descartes, René. The Philosophical Writings of Descartes. Edited and translated by John Cottingham, Robert Stoothoff, Dugald Murdoch (and Anthony Kenny, vol. 3). 3 vols. Cambridge: Cambridge University Press, 1984-1991. [CSM for vols. 1 and 2; CSMK for vol. 3] . Euvres complètes. Edited by Charles Adam, and Paul Tannery. Paris: Vrin, 1996. [AT]

Flew, Anthony. "Personal Identity and Imagination': One Objection". Philosopby 60/231 (1985): 123-126. ["Personal Identity and Imagination"']

Fodor, Jerry. "Methodological solipsism considered as a research strategy in cognitive psychology." In Representations: Philosophical Essays on the Foundations of Cognitive Science (225-253). Brighton: Harvester Press, 1981. ["Methodological solipsism"]

Gilson, Étienne. Études sur le rôle de la pensée médiévale dans la formation du système cartésien. Paris: Vrin, 1984. [Études sur le rôle de la pensée médiévale] 
L'esprit de la Philosophie Médiévale. Paris: Vrin, 1989.

Greenspan, Patricia. Emotions and Reasons. London: Routledge, 1988.

Gueroult, Martial. Descartes selon l'ordre des raisons. 2 vols. Paris: Editions Montaigne, 1968.

Hassing, Richard F. Cartesian Psychophysics and the Whole Nature of Man. Lanham: Lexington Books, 2015. [Cartesian Psychophysics]

Hatfield, Gary. "Descartes' Physiology and its Relation to his Psychology". In The Cambridge Companion to Descartes, edited by John Cottingham (335-370). Cambridge: Cambridge University Press, 1992. ["Descartes' Physiology"]

Hoffman, Paul. "The Unity of Man". The Philosophical Review 95 (1986): 339-370.

. "Descartes's Theory of Distinction". Philosophy and Phenomenological Research 64 (2002): 57-78.

Inwood, Brad. Ethics and Human Action in Early Stoicism. Oxford: Clarendon Press, 1985.

. "Seneca and Psychological Dualism". In Passions and Perceptions. Studies in Hellenistic Philosophy of Mind, edited by Jacques Brunschwig and Martha C. Nussbaum (150-183). Cambridge: Cambridge University Press, 1993.

James, Susan. Passion and Action. The Emotions in SeventeenthCentury Philosophy. Oxford: Oxford University Press, 1997. [Passion and Action]

Kambouchner, Denis. L'Homme des passions, vol. I: Analytique; vol. II: Canonique. 2 vols. Paris: Albin Michel, 1995. [L'Homme des passions] 
Kant, Immanuel. Critique of Pure Reason. Edited and translated by Paul Guyer and Allen W. Wood. Cambridge: Cambridge University Press, 1999.

Kirkebøen, Geir. "Descartes Embodied Psychology: Descartes or Damasio's Error?". Journal of the History of the Neurosciences: Basic and Clinical Perspectives 10/2 (2001): 173-191. [“Descartes Embodied Psychology”]

Knuuttila, Simo. Emotions in Ancient and Medieval Philosophy. Oxford: Clarendon Press, 2004.

Koivuniemi, Minna; Curley, Ed. "Descartes on the MindBody Union: A Different Kind of Dualism". Oxford Studies in Early Modern Philosophy 7 (2015): 83-122. ["Descartes on the Mind-Body Union"]

LeDoux, Joseph E. The Emotional Brain. New York: Simon and Schuster, 1996.

Levi, Anthony. French Moralists: The Theory of Passions 15851649. Oxford: Clarendon Press, 1964. [French Moralists]

Llinàs, Joan Ll. "La integración de la experiencia de la unión en la filosofía". In De la metafísica a la antropología, edited by François Jaran (39-52). Valencia: Pretextos, 2014. ["La integración"]

Machamer, Peter; McGuire, J. E. Descartes's Changing Mind. Princeton: Princeton University Press, 2009.

Manzini, Frédéric. "Comme un pilote en son navire". Bulletin Cartésien XXXI, Archives de Philosophie 66/1 (2003): 163-169.

Marion, Jean-Luc. Sur le prisme metaphysique de Descartes. Paris: Presses universitaires de France, 2004. [Sur le prisme metaphysique] 
- Sur la pensée passive de Descartes. Paris: Presses universitaires de France, 2013.

- "Descartes no sujeto". In De la metafísica a la antropologia, edited and translated by François Jaran (109-121). Valencia: Pretextos, 2014.

McDowell, John. Mind and World. Cambridge; London: Harvard University Press, 1996.

Moran, Richard. Authority and Estrangement. Princeton: Princeton University Press, 2001.

Nájera, Elena. Del ego cogito al vrai homme. La doble mirada de Descartes sobre el ser humano. Valencia: Editorial UPV, 2003. [Del ego cogito al vrai homme]

Nietzsche, Friedrich. The Will to Power. Edited and translated by Reginald J. Hollingdale Walter Kaufmann. New York: Vintage, 1968.

Nolan, Lawrence. "Cartesian Trialism on Trial: The Conceptualist Account of Descartes' Human Being". In The Battle of the Gods and Giants Redux. Papers Presented to Thomas M. Lennon, edited by Patricia Easton; Kurt Smith (137-174). Leiden; Boston: Brill, 2015. [“Cartesian Trialism on Trial”]

O'Neill, Eileen. "Mind-Body Interaction and Metaphysical Consistency: A Defense of Descartes". Journal of the History of Philosophy 25 (1987), 227-245. ["Mind-Body Interaction and Metaphysical Consistency"]

Papineau, David. "The Causal Closure of the Physical and Naturalism". In The Oxford Handbook of Philosophy of Mind, edited by Brian McLaughlin; Ansgar Beckermann; Sven Walter (53-65). Oxford: Oxford University Press, 2009. 
Pavesi, Pablo E. La moral metafisica. Pasión y virtud en Descartes. Buenos Aires: Prometeo libros, 2008. [La moral metafisica]

Plato. Republic, Volume I: Books 1-5. Edited and translated by Christopher Emlyn-Jones and William Preddy. Cambridge, Massachusetts: Harvard University Press, 2013. [Republic]

Prinz, J. Jesse. Gut Reactions: A Perceptual Theory of Emotion. New York: Oxford U. P., 2004a. [Gut Reactions]

Prinz, J. Jesse. "Which emotions are basic?". In Emotion, evolution and rationality, edited by Dylan Evans and Pierre Cruse (69-87). Oxford: Oxford University Press, 2004b.

Radner, Daisie. "Descartes' Notion of the Union of Mind and Body". Journal of the History of Philosophy 9 (1971): 159-170.

Putnam, Hilary. The Threefold Cord: Mind, Body, and World. New York: Columbia University Press, 1999. [The Threefold Cord]

Reiss, Timothy. "Denying the Body? Memory and the Dilemmas of History in Descartes". Journal of History of Ideas 57/ 4 (1996): 587-607. ["Denying the Body?"]

Richardson, Robert C. 'The 'Scandal' of Cartesian Interactionism". Mind 91/361 (1982): 20-37. ["The 'Scandal'"]

Röd, Wolfgang. "Descartes' Mythus oder Ryles Mythus. Überlegungen zu Ryles Descartes-Kritik". Archiv für Geschichte der Philosopbie 55/3 (1973): 310-337. [“Descartes' Mythus oder Ryles Mythus"]

Rodis-Lewis, Geneviève. L'individualité selon Descartes. Paris: Vrin, 1950a. 
. Le problème de l'inconscient et le cartésianisme. Paris: Presses universitaires de France, 1950b. [Le problème de l'inconscient]

Rorty, Amélie O. "Descartes on Thinking with the Body". In The Cambridge Companion to Descartes, edited by John Cottingham (371-392). Cambridge: Cambridge University Press, 1992.

Rorty, Richard. Philosophy and the Mirror of Nature. Princeton, N. J.: Princeton University Press, 1979.

Rozemond, Marleen. "Descartes on Mind-Body Interaction: What's the Problem?". Journal of the History of Philosophy 37/3 (1999): 435-467. ["Descartes on Mind-Body Interaction"]

. "The Nature of the Mind". In The Blackwell Guide to Descartes' Meditations, edited by Stephen Gaukroger (48-66). Malden, MA: Routledge.

Ryle, Gilbert. The Concept of Mind. London: Routledge, 2009.

Sawday, Jonathan. The Body Emblazoned: Dissection and the Human Body in Renaissance Culture. London: Routledge, 1995. [The Body Emblazoned]

Searle, John R. Minds, Brains and Science. Cambridge: Harvard University Press, 1984.

Seneca. Anger, Mercy, Revenge. Edited and translated by Robert A. Kaster and Martha C. Nussbaum. Chicago, Illinois: The University Of Chicago Press, 2012.

Shapiro, Lisa. "Descartes' Passions of the Soul and the Union of Mind and Body". Archiv für Geschichte der Philosophie 85 (2003a): 211-248. [“Descartes' Passions of the Soup'] "The Health of the Body-Machine? Or Seventeenth Century Mechanism and the Concept of 
Health". Perspectives on Science 11/4 (2003b): 441-442. ["The Health of the Body-Machine"]

Shoemaker, Sydney. The First Person Perspective and Other Essays. Cambridge: Cambridge University Press, 1996. [The First Person Perspective]

Simmons, Alison. "Re-Humanizing Descartes". Philosophic Exchange 41/1 (2013): 53-71.

"Mind-Body Union and the Limits of Cartesian Metaphysics". Philosophers' Imprint 17/14 (2017): 1-36.

Skirry, Justin. Descartes and the Metaphysics of Human Nature. New York: Thoemmes-Continuum Press.

Snider, Alvin. "Cartesian Bodies". Modern Pbilology 98/2 (2000): 299-319.

Solomon, Robert C. "On emotions and Judgements". American Philosophical Quarterly 25 (1988): 183-191.

Strawson, Peter F. Freedom and Resentment and Other Essays. London: Methuen, 1974. [Freedom and Resentment]

Sutton, John. Philosophy and Memory Traces: Descartes to connectionism. Cambridge: Cambridge University Press, 1998 [Philosophy and Memory Traces].

. "The Body and the Brain". In Descartes' Natural Philosophy, edited by Stephen Gaukroger; John Sutton; John Schuster (697-722). London: Routledge, 2000.

Taylor, Charles. Sources of the Self. Cambridge, Massachusetts. Harvard University Press, 1989.

Temkin, Owsei. Galenism: Rise and Decline of Medical Philosophy. Ithaca, New York: Cornell University Press, 1973. [Galenism] 
Verbeek, Theo. Descartes and the Dutch: Early Reactions to Cartesian Philosophy. Carbondale: Southern Illinois University Press, 1992. [Descartes and the Dutch]

Voss, Stephen. "Descartes: The End of Anthropology". In Reason, Will and Sensation: Studies in Descartes's Metaphysics, edited by John Cottingham (273-306). Oxford: Clarendon Press, 1994.

Williams, Bernard. Descartes: The Project of Pure Enquiry. London: Routledge, 2005. [Descartes]

Williston, Byron. "The Cartesian Sage and the Problem of Evil". In Passion and Virtue in Descartes, edited by Byron Williston and André Gombay (301-331). Amherst, New York: Humanity Books, 2003. ["The Cartesian Sage"']

Wilson, Margaret. Descartes. Boston: Routledge and K. Paul, 1978.

(cc) EY 